\title{
The phylogenetic affinities of Nothofagus (Nothofagaceae) leaf fossils based on combined molecular and morphological data
}

Gregory J. Jordan ${ }^{1}$ and Robert S. Hill ${ }^{2}$

School of Plant Science, University of Tasmania, G.P.O. Box 252-55, Hobart, Tas. 7001, Australia. e-mail: greg.jordan@utas.edu.au

The phylogenetic placements of leaf fossils of Nothofagus (Nothofagaceae) were determined using parsimony analyses of molecular and morphological data for extant species combined with morphological data for fossils. Placement was possible for only seven of the thirty or so described fossil species of Nothofagus because only these had sufficiently good preservation of both cuticular and leaf architectural characters. In combined analyses of morphology and molecular data leaf cuticular characters showed little homoplasy. In contrast, many architectural characters, including some leaf margin and venation characters, showed high homoplasy, making it difficult or impossible to accurately determine the phylogenetic affinities of impression fossils of this genus.

${ }^{1}$ Author for correspondence and reprints. E-mail: greg.jordan@utas.edu.au ${ }^{2}$ Current address: Department of Environmental Biology, University of Adelaide, South Australia, 5005, Australia. 


\section{Introduction}

The use of phylogenetic methods to establish the relationships of plant fossils has often been encouraged (e.g. Crane 1985; Nixon 1996) and there has been a recent trend towards using combined analyses of fossil and extant taxa of well preserved reproductive organs (e.g. Manchester and Donaghue 1995; Keller et al. 1996; Crepet and Nixon 1998a,b). Most of these studies have used only morphological characters, and in some cases phylogenies using different interpretations of morphology differ significantly from each other (e.g. Crepet and Nixon 1998b), and from molecular based phylogenies, for example compare the phylogenies published by Crepet and Nixon (1998b) with those of Chase et al. (1993) and Soltis et al. (1997). Thus, use of phylogenies based on morphology without reference to molecular data may not lead to robust phylogenetic placement of fossils. This applies in particular to leaf fossils because relatively few characters can be scored on them, even in comparison with many fossil reproductive structures.

Nothofagus is one of the few extant genera in the Southern Hemisphere with both a well researched phylogeny and a rich fossil record. Relationships among extant species of Nothofagus are relatively well understood, as a result of research by many authors (Melville 1973; Humphries 1981; Hill and Jordan 1993; Martin and Dowd 1993; Manos 1997; Setoguchi et al. 1997). Phylogenies based on morphological data have been reassessed and refined several times (Melville 1973; Humphries 1981; Hill and Jordan 1993; Manos 1997). Recent phylogenies based on morphology (Manos 1997), chloroplast DNA ( $r b c$; Martin and Dowd 1993; Setoguchi et al. 1997), and nuclear DNA (ITS; Manos 1997) show strong congruence with each other. Combined analysis of these data therefore produces a robust phylogeny of Nothofagus. An important feature of this phylogeny is the clear monophyly of the four subgenera (Brassospora, Nothofagus, Fuscospora and Lophozonia) defined by Hill and Read (1991) with names revised by Hill and Jordan (1993).

The fossil record of Nothofagus has been reviewed by Tanai (1986) and Hill (1991). It includes leaf, fruit, wood and pollen from various parts of the Southern Hemisphere. Over 30 species of the genus have been described based on leaf fossils in Tasmania (see Hill 1991; Jordan in press), south-eastern Australia (e.g. Pole et al. 1993; Scriven et al. 1995), Argentina (e.g. Romero and Dibbern 1985; Tanai 1986), New Zealand (e.g. Kovar et al. 1987; Pole 1993) and the Transantarctic Mountains (Hill et al. 1996). Leaf fossils of Nothofagus range in 
age from Early Tertiary (Hill 1991) to Late Pleistocene (e.g. Jordan et al. 1991), although the pollen record extends back to the Late Cretaceous (Dettmann 1994). Some leaf and cupule fossils (e.g. Hill 1991; Scriven and Hill 1996) have been classified into the subgenera, and fossil pollen is categorised into groups which match the subgenera (Dettmann et al. 1990; Hill and Read 1991).

The phylogenetic placement of Nothofagus fossils is interesting because many fossils provide evidence of former distributions well outside of modern biogeographic boundaries. For instance some Early Tertiary Tasmanian leaf and cupule fossils have been assigned to subgenera which are now restricted to South America (subgenus Nothofagus) and to New Guinea and New Caledonia (subgenus Brassospora) (Hill 1991; Scriven and Hill 1996). Distributions of fossil pollen also contrast with the modern distributions of subgenera (e.g. Dettmann et al. 1990; Macphail et al. 1994). The co-occurrence of fossils with temperate (subgenera Lophozonia, Fuscospora and Nothofagus) and tropical (subgenus Brassospora) affinities also has palaeoecological implications (e.g. Hill 1991; Read et al. 1990).

This work uses an integrated molecular and morphological data set for extant species to establish a phylogenetic framework in which the relationships of Nothofagus leaf fossils can be assessed. Morphological data for well preserved leaf fossils were combined with vegetative and reproductive morphological data, Manos' (1997) nuclear DNA and Martin and Dowd's (1993) chloroplast DNA for extant species of Nothofagus. Phylogenetic placements of the fossils are determined using parsimony analysis of this large combined data set. In effect, this imposes phylogenetic topologies which are consistent with a wide range of data on the morphological characters measured in fossils. It also allows an assessment of the value of leaf morphological and anatomical traits in determining the phylogenetic affinities of Nothofagus leaf fossils.

\section{Materials and Methods}

Extant Nothofagus Species

Only those extant species of Nothofagus for which morphological, ITS and $r b c \mathrm{~L}$ data were all available were included to minimise the amount of missing data. This included all extant species of subgenera Nothofagus, Fuscospora and Lophozonia recognised by Hill and Read 
(1991), but only six out of approximately 15 extant species of subgenus Brassospora because of the availability of molecular data.

\section{Fossil Taxa}

All described fossil species of Nothofagus were investigated, but only seven fossil taxa were included in formal analyses (Table 1). These were all the species of leaf fossils (excluding those assigned to extant species) which could be coded for all the venation and cuticular characters used here. Most of the described species not included in this analysis are based on fossils in which cuticular preservation is relatively poor or non-existent (e.g. Tanai 1986; Pole 1993; Pole et al. 1993; Hill et al. 1996). Two of the included taxa, Nothofagus serrata and N. mисronata, although apparently clearly distinct species, were treated as a single terminal taxon, because the features that distinguish them are autapomorphic, or cannot be reliably coded in other taxa. The leaves of these species differ in that the former are elliptical, have straight secondary veins and the apices are acute and emarginate, whereas those of the latter are obovate, have curved secondary veins, the apices are obtuse and mucronate, and waxes are more strongly developed than in the previous species. The obovate leaf shape, and obtuse and mucronate apex are autapomorphic, whereas the path of secondary veins and development of waxes are poorly defined and difficult to score in other species. All of the fossil taxa except $N$. serrata and $N$. mucronata were represented by a large number (> 50) of nearly complete leaves with good preservation of cuticle. Nothofagus serrata and N. mucronata were represented by fewer leaves, but these are very well preserved.

All the fossil species have been assigned to subgenera based on morphological or cuticular features (Table 1). One species, N. microphylla, was transferred from subgenus Lophozonia to subgenus Nothofagus by Scriven and Hill (1996), mainly because its stomata had T-shaped thickenings at their poles. Nothofagus pachyphylla, N. mucronata, N. serrata and N. microphylla are each known from only one site. Nothofagus tasmanica is known from four Oligocene sites in Tasmania (Hill 1983, 1991; Scriven and Hill 1996). This species is variable and may contain the equivalent of several modern species, but the analyses here treated this complex as a single species because, like $N$. serrata and $N$. mucronata, the differences were either autapomorphic or in ambiguous characters. Nothofagus lobata occurs at two Early Oligocene Tasmanian sites (Hill 1991; Scriven and Hill 1996). Nothofagus maidenii is known from Late Oligocene/Early Miocene sediments at Berwick Quarry, Victoria (Deane 1902; Pole 
et al. 1993), and at Pioneer, Tasmania, but this study is primarily based on the specimens from Pioneer. Specimens of this species from Berwick Quarry are not well enough preserved for this analysis, but are consistent in the available characters with the specimens from Pioneer. The Pioneer specimens were originally described as N. johnstonii R.S.Hill (Hill 1983).

\section{Molecular Data}

Paul Manos provided copies of all the molecular data. ITS (intergene spacer) nuclear DNA data were derived from Manos (1997). $r b c \mathrm{~L}$ data for 23 species sequenced by Martin and Dowd (1993) are available from Genbank (L13340 - L13346, L13348, L13350 - L13363). $r b c \mathrm{~L}$ for Nothofagus aequilateralis was sequenced by Paul Manos. $r b c \mathrm{~L}$ sequences for Betula nigra (L12634) and Corylus cornuta (X56619) came from Genbank. Manos (1997) gives details of the alignment of the DNA sequences. The data were restricted to phylogenetically informative characters.

\section{Morphological Characters}

The characters used in the analyses are listed in Table 2, and the data matrix is shown in Table 3. Characters 14 - 24 were coded for fossil species from specimens, with reference to their published descriptions (Table 1). Note that Hill and Read (1991) recorded the presence of SUTTA in N. tasmanica from Little Rapid River, but this was a typographic error for SUTTC. Coding for extant species was as follows.

All characters were unordered. Characters 1, 4, 5, 8, 9, 11 - 16 and 18 - 21 were coded for extant species following Hill and Jordan (1993).

Character two combined information from cupule valve number, number of fruit and number of locules because they are probably developmentally linked (Rozefelds 1997; A. C.

Rozefelds personal communication). These were scored as two or three separate characters by Hill and Jordan (1993) and Manos (1997) respectively, but the coding here makes fewer assumptions.

Character three (cupule appendage type) followed Manos (1997). 
Character six (staminate flowers) was derived from Rozefelds and Drinnan (1998), and implies that the number of stamens per flower, as used by Hill and Jordan (1993) and Manos (1997), was a misinterpretation. The character used here differentiates the two forms identified by Rozefelds and Drinnan (1998). A true perianth is present in the staminate flowers of most species, but in species of subgenus Lophozonia three flowers occur together and are surrounded by a perianth-like structure (a pseudanthium).

Character seven (pollen shape) differed from Manos' treatment in that species of subgenus Lophozonia were coded as peritreme rather than goniotreme (see Dettmann et al. 1990 and Hanks and Fairbrothers 1976).

Character 10 (pollen diameter) is based on data from Hanks and Fairbrothers (1976).

Character 16 (solitary unicellular trichome type C: SUTTC) codes the unique trichome type in the fossil N. pachyphylla as a form of SUTTC. SUTTC and the unique trichome type in $N$. pachyphylla are the only trichomes in the genus with a hollow base, and differ only in that epidermal cells surrounding the hollow based trichomes in N. pachyphylla are thick walled and raised (also see the discussion).

Character 17 (conical trichomes) differed from Hill and Jordan (1993) in including two additional states. Narrow conical trichomes expanding rapidly near the base to become much enlarged (at least $30 \mu \mathrm{m}$ wide in some trichomes) and with thickened bases (Fig. 1A) were treated as a separate state. Conical trichomes of other species can have large bases, but in these cases the bodies of these trichomes themselves are always very large. Two of Hill and Read's (1991) trichome types, SUTTB and SUTTD, are treated as being conical trichomes because there is intergradation between conical trichomes, SUTTB and SUTTD. Contrary to Hill and Jordan (1993), conical trichomes are present in N. gunnii and N. fusca.

Character 20 (giant stomata on veins) is defined as the presence or absence on the veins of stomata which are at least twice as long as the typical size of stomata in the interveinal areas. It differed from the data of Hill and Jordan (1993) in that it is coded as present in $N$. cunninghamii (Fig. 1B). 
Character 22 (upper epidermis) was coded from the cuticle collection described by Hill and Read (1991). The epidermal cells over veins may form a distinct reticulum by being elongate (State 0: Fig. 1C), or because the epidermal cells in areoles are thicker than those over the veins and appear to bulge in cuticle preparations (State 1: Fig. 1D), or may be uniform across the lamina (State 2: Fig. 1E).

Character 23 (complete fimbrial vein) differed from Manos' (1993) character, in having three states. In many taxa there is no, or a very discontinuous fimbrial vein (State 0 ). In others fimbrial veins branch off intersecondary veins (State 2: Fig. $1 F$ ). In other species the fimbrial veins arise in the petiole (State 1: Fig. 1G). Also, contrary to Manos (1997), N. solandri has a strong fimbrial vein arising in the petiole (Fig. $1 H$ ).

Character 24 (serrations) described the relationship of secondary veins to teeth and was scored from cleared leaves used by Hill and Read (1991). Some species have distinctly multiple teeth (State 0: Fig. 1I), in others most teeth are single ( State 1: Fig. $1 J$ ), others have entire margins (State 2). Poole and Adams (1986) and Gandolfo and Romero (1992) used this character in distinguishing among Nothofagus species from New Zealand and South America.

Stamen ornamentation, stamen size and fusion of the filaments (Rozefelds 1998) were not included because they were not phylogenetically informative in the analyses here. These characters primarily vary among species of subgenus Brassospora, but data for these characters were not available for the outgroup or for the New Caledonian species of subgenus Brassospora used here.

\section{Outgroup}

This work uses Betulaceae as an outgroup as suggested by Nixon (1989), and for the following reasons. Phylogenetic analyses of two chloroplast genes ( $r b c \mathrm{~L}$ and $m a t \mathrm{~K})$ suggest that Nothofagus is basal to a group of higher hamamelid families, including Betulaceae, Casuarinaceae, Fagaceae, Myricaceae, Ticodendraceae and Rhoipteleaceae (Manos and Steele 1996), so that any of these families is a potential outgroup. Some earlier analyses (e.g. Hill and Jordan 1993) used Fagus to polarise morphological data in Nothofagus because of apparent similarity in the female reproductive structures, but the structures do not appear to be homologous (Rozefelds 1997). Many of the cuticular features critical to the present study 
occur within Betulaceae, but appear to be replaced in Fagaceae by structures which are difficult to interpret in terms of homology. Also both data for both ITS and $r b c \mathrm{~L}$ were available for Betulaceae, but not Fagus. Betulaceae was scored for ITS and $r b c \mathrm{~L}$ data based on two genera of Betulaceae, Betula and Corylus as suggested by Manos and Steele (1997), and for morphological characters based on inspection of seven species (Alnus rubra Bong., A. incarna (L.) Moench, Betula pendula Roth, B. raddeana Trautv., B. alba L., B. pubescens Ehrh. and Carpinus carolineana Walt.). Betulaceae was scored as unknown for reproductive traits because the homology of these characters in Nothofagus with those in Betulaceae is very unclear. The use of multiple outgroups (such as including Fagus, as in Manos 1997) had little affect on the topology for extant species, but was inappropriate for analyses of fossils because of noise apparently introduced by very large amounts of missing data.

\section{Cladistic Analyses}

Parsimony searches were performed with the heuristic search algorithm of PAUP 4.0b1 (Swofford 1998) on a number of subsets of the matrix containing all characters and all species (Table 4). Each analysis used 100 replicates of random addition of taxa and tree bisectionreconnection (TBR) branch swapping, holding five trees at each step and saving all the most parsimonious trees. Multistate taxa were treated as polymorphisms.

The first matrix included all the extant species and the ITS, $r b c \mathrm{~L}$ and morphological data (analysis 1, Table 4). This analysis tested whether the results of Manos (1997) were reproduced with the slightly modified data used here. The most parsimonious trees found by heuristic methods were confirmed using the branch and bound algorithm of PAUP 4.0b1 (Swofford 1998). The branch support for the trees derived from this matrix was assessed by searching for the additional number of steps for a branch to collapse (Bremer support, also known as decay index: Bremer 1988; Källersjö et al. 1992; Farris 1996). Bremer support does not directly reflect probability, but large numbers indicate strong branch support (Källersjö et al. 1992).

The ability to determine the phylogenetic placement of a taxon based only on leaf characters (as is the case with fossils) was tested using analyses of 22 matrices (analyses 2-23; Table 4). For each extant species, a matrix was created with that species coded for leaf characters but with missing values for all the other characters (and thus simulating a leaf fossil species), plus 
the other 21 extant species with all characters coded. The phylogenetic placement of each extant species based on the complete data was then compared with its placement using characters that can be measured on fossils.

The most parsimonious position of the fossils was determined using analysis of a matrix (analysis 24; Table 4) including all the data from the first analysis, plus the leaf morphological and anatomical data for the six fossil terminal taxa ( $N$. mucronata and $N$. serrata as a single terminal, plus the five other species). To compare the power of analyses using the combined molecular and morphological data, with those just using morphological data measurable on fossils, this analysis was repeated on a matrix containing only leaf characters (analysis 25; Table 4).

Six matrices (analyses 26-31; Table 4) were used to test the extra tree length required to place each fossil species in less parsimonious parts of the tree. Each matrix included all the characters for all the extant species and one of the fossil terminal taxa. The length of the most parsimonious tree for the matrix was compared with the most parsimonious trees under constraints. The constraints were such that certain groups were monophyletic, but were otherwise unconstrained. The constraints are of three types which are best described by examples. The alternative placement of $N$. pachyphylla in subgenus Brassospora was tested by constraining the trees such that $N$. pachyphylla and the extant species of subgenus Brassospora formed a monophyletic group. In this type of constraint, the group was selected so that it contained strongly supported monophyletic groups of extant species, plus one fossil. A second example is that the placement of $N$. pachyphylla as basal to the clade formed from subgenera Brassospora and Nothofagus was tested by constraining the trees such that $N$. pachyphylla was a sister to a monophyletic group containing the extant species of those subgenera. The final example is that the placement of $N$. pachyphylla as sister to $N$. cunninghamii was tested by constraining the tree to not contain those two species as a monophyletic group. Because of the small number of informative characters available on the fossils (11) compared to the large number for extant species (165), the additional number of steps required for alternative placements of fossils are not directly comparable to the Bremer support for extant species in the combined analysis. 
The final matrix included all the extant species, but only those characters which could be measured on fossils with good preservation of both cuticular and architectural features (analysis 32; Table 4). This matrix was used to test whether the phylogenies derived from the characters measurable on leaf fossils were congruent with the best available phylogeny derived from the combined analysis.

\section{Results}

Analyses of Extant Species

The combined analysis of extant species (analysis 1) produced two most parsimonious trees (Fig. 2). The strict consensus of these trees was almost identical to Manos' (1997) consensus tree for combined data. They differed only in the topology among the New Guinea members of subgenus Brassospora, and that N. antarctica and N. pumilio are sister species in Manos' (1997) consensus, but, in the consensus from the present analysis, there is an unresolved trichotomy among these two species and a clade containing $N$. nitida and $N$. betuloides. The support for several clades is very strong, in particular for the subgenera Brassospora, Nothofagus and Fuscospora, for these three as a group, and for the evergreen members of subgenus Lophozonia (Fig. 2). Both subgenus Lophozonia and the clade comprising the deciduous species of subgenus Lophozonia are relatively weakly supported. Support for most branches within these clades is also relatively weak.

In the analyses of extant species treated as if they were fossils (analyses 2-23), 19 of the 22 extant species were placed into the same subgenera (Fig. 3) as in the full analysis (Fig. 2). The exceptions were the three deciduous species of subgenus Lophozonia which were ambiguously placed; either within Lophozonia or basal to the large clade of other species (Fig. 3). In contrast to the high success rate at the subgeneric level, the topologies within subgenera varied markedly (Fig. 3). The consensus trees were identical to that in Fig. 2 for only three species (N. fusca, N. solandri and N. truncata), For nine species (N. grandis, N. perryi, N. antarctica, N. pumilio, N. alessandri, N. gunnii, N. alpina, N. glauca and N. obliqua) the trees were completely (or almost completely) unresolved within the relevent subgenus. For the remaining 10 species the trees were resolved but incogruent with the consensus from combined data in Figure 2. Thus 10 out of 22 species would have been placed in different phylogenetic positions to their placement based on the combined data if they had been only known as fossils, and most of the rest would have been placed ambiguously. 


\section{Analyses of Fossil Species}

The fossil species can be incorporated into the combined phylogeny (analysis 24; Fig. 4) with little additional homoplasy. When restricted to the characters that are measured on the fossils (characters 11-24), the consistency index for the two most parsimonious trees from the combined analysis of extant species (analysis 1; Fig. 2) is 0.47 , and that for the 90 most parsimonious trees from the combined analysis of extant and fossils (Fig. 4) is 0.44.

The fossil species $N$. pachyphylla, N. maidenii and N. tasmanica require relatively large numbers of steps to be placed in subgenera other than Lophozonia, or on basal branches, which implies that they are strongly supported as members of this subgenus Lophozonia (analyses 26-28; Fig. 5A-C). Nothofagus pachyphylla is the sister species of the extant species N. cunninghamii (Fig. 4). Placement anywhere else requires at least two more steps. Nothofagus maidenii is the sister to the $N$. cunninghamii/N. pachyphylla clade, but the support for this is not strong since it would only take one more step to place it elsewhere within subgenus Lophozonia. The position of Nothofagus tasmanica within the evergreen clade of subgenus Lophozonia is unresolved, except that it is placed outside the Nothofagus maidenii/N. cunninghamii/N. pachyphylla clade (Fig. 4).

The fossil species N. microphylla is placed as basal to the evergreen members of subgenus Lophozonia, but this is only weakly supported (analysis 29; Fig. 5D). Alternative placements are in more basal positions or in subgenus Nothofagus (Fig. 5D).

The fossil species $N$. serrata and $N$. mucronata are strongly supported as members of subgenus Brassospora (analysis 30; Figs 4, 5E). They are placed as either basal to the members of the subgenus represented in this analysis, or as sister species nested within the extant species.

The fossil species $N$. lobata is best described as the sister species of the extant species $N$. nitida (Fig. 4), though it would only take one more step to place it elsewhere within subgenus Nothofagus. Its placement within subgenus Nothofagus is strongly supported (analysis 31; Fig. $5 F)$. 


\section{Analyses Using Only Leaf Characters}

The analysis using only characters which can be scored from fossil leaves with good cuticular preservation produced 12 shortest trees (analysis 32; Fig. 6). These trees are not congruent with the combined analysis (Fig. 2), although each subgenus is monophyletic apart from subgenus Lophozonia where evergreen species are placed basal to subgenus Brassospora, and the deciduous members are part of an unresolved basal polychotomy. The consensus for extant and fossil taxa (204 equally parsimonious trees 31 steps long, not shown) using only these leaf characters was much more poorly resolved than the analysis including all characters (Fig. 2). Among the fossils, only N. lobata and N. mucronata were included within subgeneric clades. The consensus of trees only one step longer was totally unresolved, apart from a monophyletic subgenus Nothofagus.

In the trees of extant species (analysis 1; Fig. 2), cuticular characters (characters 14-22) mostly showed high $(\geq 0.5)$ consistency indices which were not altered with the addition of the fossil species (analysis 24; Fig. 4) (Table 5). The consistency indices for the architectural characters (character 23 and 24) were low $(\leq 0.4)$.

\section{Discussion}

The Utility of this Methodology in Classifying Nothofagus Fossils

The congruence between three more or less independent data sets (morphology, ITS and $r b c \mathrm{~L}$ ) shown by Manos (1997), and the strong support for the major branches, suggests that the combined morphological and molecular data provide a strong framework for the classification of fossils. The poor resolution of the phylogeny of extant species constructed using only data available in fossils (analysis 32; Fig. 6) and its incongruence with the combined tree (Fig. 2) imply that phylogenetic placement of Nothofagus leaf fossils is dependent on incorporating molecular and morphological data from extant species.

The "correct" assignment to subgenera of the extant species (except the three deciduous species of subgenus Lophozonia) when they were restricted, one by one, to data available for fossils (analyses 2- 23; Fig. 3), suggests that most well preserved leaf fossils of Nothofagus can be reliably assigned to subgenera. The deciduous species of subgenus Lophozonia are a special case because they form a near basal, poorly supported clade in the combined analysis. It would be difficult to discriminate fossils of this clade from Betulaceae because of a lack of 
derived characters. Resolution within subgenera is very poor, suggesting poor support for fine-resolution classification.

Relatively high consistency indices suggest that cuticular characters are useful in classifying fossil Nothofagus leaves. In contrast, leaf architecture appears much less useful, because architectural characters in this analysis (Table 5) and others used by other authors to classify fossil Nothofagus leaves show low consistency with the combined phylogeny of extant species. For example, rounded teeth (Gandolfo and Romero 1992), arose at least three times (in N. pumilio, in N. gunnii and in subgenus Brassospora), and reticulate tertiary veins (Gandolfo and Romero 1992) arose at least twice (in subgenera Brassospora and Fuscospora). Some architectural features, such as the thickness of terminal veinlets (Tanai 1986), may be linked to habit (evergreen/deciduous), which has changed at least four times in the genus (Hill and Jordan 1993; Manos 1997). All extant species with thick veinlets are evergreen and those with thin veinlets are deciduous.

The number and strength of cuticular characters, together with the relative weakness of architectural characters, implies that robust determination of the phylogenetic affinities of Nothofagus leaf fossils will usually require good cuticular preservation. The assignment of most leaf impressions, including many of the fossils excluded from this analysis, to subgeneric groups within Nothofagus (e.g. Tanai 1986) is, therefore, unrealistic. The main exceptions are impression fossils with distinctive architectural apomorphies, e.g. fossil $N$. gunnii from Tasmania (Hill 1984, 1991) and N. crenulata (Engelhardt) Dusén from South America (Tanai 1986), which have the distinctive margin types of extant $N$. gunnii and $N$. antarctica, respectively. However, even these cases depend upon a lack of convergence in the critical characters. It may be possible to classify some of the other excluded fossil species if fresh specimens are collected and cuticles are processed immediately. However many are deciduous, which often means that cuticles are very thin and fragile.

\section{The Phylogenetic Placement of the Fossils}

This work supports Hill's (1991) subgeneric placements of N. maidenii, N. tasmanica (subgenus Lophozonia), N. lobata (subgenus Nothofagus), N. serrata and N. mucronata (subgenus Brassospora) and Jordan's (in press) placement of N. pachyphylla (subgenus Lophozonia). However, the poor capacity to classify fossils within subgenera implied by Fig. 
3 suggests that leaf fossils do not provide enough phylogenetic information to establish evolutionary sequences within subgenera without additional information. Such information might include stratigraphic position, or data on characters which are more useful within groups than among groups (e.g. Hill's 1993 treatment of subgenus Lophozonia), though use of these sorts of data may depend on extra assumptions.

The main conflict between the results obtained here and established taxonomy is that $N$. microphylla is nested within subgenus Lophozonia, whereas Scriven and Hill (1996) assigned this species to subgenus Nothofagus. It is notable that the critical character used by Scriven and Hill, "T-pieces at stomatal poles", shows no homoplasy in the combined analysis of extant species. The support for the subgeneric placement of $N$. microphylla is relatively weak, so it is probably best treated as ambiguous.

The morphological data used here is only one of many possible interpretations of morphology. Alternative data sets either make more complex assumptions about some characters than are made here, or give essentially the topologies found here. For example, the hollow based trichomes in N. pachyphylla are unique (Jordan in press) but are interpreted here as being homologous to the trichome type, SUTTC. Data sets assuming that these two trichome types are not homologous place $N$. pachyphylla in the same place.

A potential problem arises from conical trichomes and SUTTC which are not present on all leaves of some plants. Cuticles from several leaves may need to be searched to score these characters. This is a problem for rare fossils with fragmentary cuticles, and the absence of trichome types may need to be treated as being ambiguous. However, none of the taxa here are likely to be seriously affected: most have both SUTTC and conical trichomes, the others are either represented by abundant specimens, or their placement is unchanged when the problematic characters are scored as ambiguous.

\section{Implications for General Palaeobotany}

This methodology can classify fossils in a robust, repeatable and relatively objective way, and provides a means of assessing alternative phylogenetic placements of fossil taxa. However, it is dependent on a data rich, robust phylogeny being available for the extant taxa, which, as yet, is available for relatively few groups of plants. It also depends on enough phylogenetically 
meaningful traits being available on the fossils. For Nothofagus this requires the preservation of both cuticle and leaf architecture.

The relative phylogenetic value of cuticular and architectural characters in other taxa is less well known than in Nothofagus. The homoplasious nature of leaf architectural traits in Nothofagus (Table 5) suggests that the identification of taxa based only on leaf impressions should be treated with caution unless very distinctive and derived architectural features are preserved. Leaf architectural traits may be more informative in other groups, but this needs to be confirmed by phylogenetic methods.

\section{Acknowledgments}

We thank Paul Manos for molecular data, Andrew Rozefelds for discussion on inflorescence morphology and comments on a draft, Ulf Swenson for help with cladistic methods and Dot Steane for comments on the molecular data. This work was supported by an A.R.C. large grant to R.S.H.

\section{Literature Cited}

Bremer K 1988 The limits of amino acid sequence data in angiosperm phylogenetic reconstruction. Evolution 42: 795-803.

Chase M, DE Soltis, RG Olmstead, D Morgan, DH Lees, BD Mishler, MR Duvall, RA Price, HG Hills, Y-L Qiu, KA Kron, JH Rettig, E Conti, JD Palmer, JR Manhart, KJ Sytsma, WJ Kress, KG Karol, WD Clark, M Hedren, BJ Gaut, RK Jansen, CE Wimpel, JF Smith, GR Furnier, SH Strauss, Q-Y Xiang, GM Plunkett, PS Soltis, SM Swenson, SE Williams, PA Gadek, CJ Quinn, LE Eguiarte, E Golenberg, GH Learn, SW Graham, SCH Barret, S Dayananden, VA Albert 1993. Phylogenetics of seed plants: an analysis of nucleotide sequences from the plastid gene rbcL. Ann Mo Bot Gard 80: 526-579.

Crane PR 1985 Seed plant phylogenetics. Ann Mo Bot Gard 72: 716 - 793.

Crepet WL, KC Nixon 1998a. Fossil Clusiaceae from the Late Cretaceous (Turonian) of New Jersey and implications regarding the history of bee pollination. Am J Bot 85: 1122-1133.

Crepet WL, KC Nixon 1998b. Two new fossil flowers of magnoliid affinity from the Late Cretaceous of New Jersey. Am J Bot 85: 1273-1288.

Deane H 1902 Notes on the fossil flora of Berwick. Records Geol Soc Vic 1: 21-32.

Dettmann ME 1994 Cretaceous vegetation: the microfossil record. Pages 143-170 in RS Hill, 
ed. History of the Australian vegetation: Cretaceous to Recent. Cambridge University Press, Cambridge.

Dettmann ME, DT Pocknall, EJ Romero, MC Zamaloa 1990 Nothofagidites Erdtman ex Potonie, 1960: a catalogue of species with notes on the palaeogeographic distribution of Nothofagus B1. (Southern Beech). NZ Geol Surv, Lower Hutt, New Zealand. 79 pp.

Farris JS 1969 A successive approximations approach to character weighting. Syst Zool 18: 374-385.

Farris JS 1989 The retention index and the rescaled consistency index. Cladistics 5: 417-419. Farris JS 1996 Names and origins. Cladistics 12: 263-264.

Gandolfo MA, EJ Romero 1992 Leaf morphology and a key to species of Nothofagus Bl. Bull Torrey Bot Club 119: 152-166.

Hanks SL, DE Fairbrothers 1976 Phytotaxonomic investigation of FagusL. and Nothofagus B1.: light microscopy, scanning electron microscopy, and computer analyses. Pages 1-141 in VH Heywood, ed. Botanical Systematics, an Occasional Series of Monographs. Academic Press, London.

Hill RS 1983 Nothofagus macrofossils from the Tertiary of Tasmania. Alcheringa 7: 169-183. Hill RS 1984 Tertiary macrofossils from Cethana, Tasmania. Alcheringa 8: 81-86.

Hill RS 1991 Tertiary Nothofagus (Fagaceae) macrofossils from Tasmania and Antarctica and their bearing on the evolution of the genus. Bot J Linn Soc 105: 73-112.

Hill RS, DM Harwood, P-N Webb 1996 Nothofagus beardmorensis (Nothofagaceae), a new species based on leaves from the Pliocene Sirius Group, Transantarctic Mountains, Antarctica. Rev Palaeobotany Palynology 94: 11-24.

Hill RS, GJ Jordan 1993 The evolutionary history of Nothofagus (Nothofagaceae). Aust Syst Bot 6: 111-126.

Hill RS, J Read 1991 A revised infrageneric classification of Nothofagus (Fagaceae). Bot J Linn Soc 105: 37-72.

Humphries CJ 1981 Biogeographical methods and the southern beeches (Fagaceae:

Nothofagus). Pages 177-207 in VA Funks and DR Brooks, eds. Advances in Cladistics. New York Botanic Garden, New York.

Jordan, GJ. in press. A new Early Pleistocene species of Nothofagus and the climatic implications of co-occurring Nothofagus fossils. Aust Syst Bot 12.

Jordan GJ, RJ Carpenter, RS Hill 1991 Late Pleistocene vegetation and climate near Melaleuca Inlet, south-western Tasmania. Aust J Bot 39, 315-333. 
Källersjö M, JS Farris, AG Kluge, C Bult 1992 Skewness and permutation. Cladistics 8: 275287.

Keller JA, PS Herendeen, PR Crane 1996. Fossil flowers and fruits of the Actinidiaceae from the Campanian (Late Cretaceous) of Georgia. Am J Bot 83: 528-541.

Kovar JB, JD Campbell, RS Hill 1987 Nothofagus ninnisiana(Unger) Oliver from Waikato Coal Measures (Eocene-Oligocene) at Drury, Auckland, New Zealand. NZ J Bot 25: 79-85. Macphail MK, N Alley, EM Truswell, IR Sluiter, 1994 Early Tertiary vegetation : Evidence from Pollen and spores. Pages 189-261 in History of the Australian Vegetation: Cretaceous to Recent. RS Hill, ed. Cambridge University Press, Cambridge.

Manchester SR, MJ Donaghue 1995. Winged fruits of Linnaeeae (Caprifoliaceae) in the Tertiary of western North America: Diplodipelta gen. nov. Int J Plant Sci 156: 709-722. Manos PS 1997 Systematics of Nothofagus (Nothofagaceae) based on rDNA spacer sequences (ITS): taxonomic congruence with morphology and plastic sequences. Am J Bot 84: 11371155 .

Manos PS, KP Steele 1997. Phylogenetic analysis of "higher" Hamamelidae based on plastid sequence data. Am. J. Bot. 84: 1407-1419.

Martin PG, JM Dowd 1993 Using sequences of $r b c$ L to study phylogeny and biogeography of Nothofagus species. Aust Syst Bot 6: 441-447.

Melville JI 1973 Continental drift and plant distribution. Pages 439-446 in DH Tarling and SK Runcorn (Eds.) Implications of continental drift to the earth sciences. Academic Press, London.

Nixon KC 1989. Origins of Fagaceae. Pages 23-43 in PR Crane and S Blackmore, Eds. Higher Hammamelidae. Systematics Association Special Volume 40B. Clarendon Press London.

Nixon KC 1996 Palaeobotany in cladistics and cladistics in palaeobotany: enlightenment and uncertainty. Rev Palaeobotany Palynology 90: 361-373.

Pole MS 1993 Early Miocene flora of the Manuherikia Group, New Zealand. 8. Nothofagus. J Roy Soc NZ 23: 329 -344.

Pole MS, RS Hill, N Green, MK Macphail 1993 The Miocene Berwick Quarry flora rainforest in a drying climate. Aust Syst Bot 6: 399-428.

Poole AL, N Adams 1986 Trees and shrubs of New Zealand. Government Printing Office Publishing, Wellington. 
Read J, GS Hope, RS Hill 1990 Integrating historical and ecophysiological studies in Nothofagus to examine the factors shaping the development of cool rainforest in south-eastern Australia. Pages 97-106 in JG Douglas and DC Christophel, Eds. Proceedings 3rd IOP Conference, Melbourne, 1988.

Romero EJ, MC Dibbern 1985 A review of the species described as Fagus and Nothofagus by Dusen. Palaeontographica B 187: 123-137.

Rozefelds AC 1997 Ontogeny of Nothofagus inflorescences. PhD diss. University of Melbourne, Australia.

Rozefelds AC 1998 Stamen morphology in Nothofagus (Nothofagaceae). Int J Plant Sci 159: 655-667.

Rozefelds AC, AN Drinnan 1998 Ontogeny and diversity in staminate flowers of Nothofagus (Nothofagaceae). Int J Plant Sci 159: 906-922.

Scriven LJ, RS Hill 1996 Relationships among Tertiary Nothofagus (Nothofagaceae) populations. Bot J Linn Soc 121: 345-364.

Scriven LJ, S McLoughlin, Hill RS 1995 Nothofagus plicata (Nothofagaceae) a new deciduous Eocene macrofossil Tertiary species, from southern continental Australia. Rev Palaeobotany Palynology 86: 199-209.

Setoguchi H, M Ono, Y Doi, H Koyama, M Tsuda 1997 Molecular phylogeny of Nothofagus (Nothofagaceae) based on the atpB- $r b c \mathrm{~L}$ intergenic spacer of the chloroplast DNA. J Plant Res 110: 469-484.

Soltis, DE, PS Soltis, DL Nickrent, LA Johnson, WJ Hahn, SB Hoot, JA Sweere, RK Kuzoff, KA Kron, MW Chase, SM Swenson, EA Zimmer, S-M Chaw, LJ Gillespie, WJ Kress, KJ Sytsma 1997. Angiosperm phylogeny inferred from 18s ribosomal DNA sequences. Ann Mo Bot Gard 84: 1-49.

Swofford DL 1998 PAUP 4.0b1: Phylogenetic Analysis Using Parsimony. Sinauer Associates Ltd, Sunderland, Massachusetts.

Tanai T 1986 Phytogeographic and phylogenetic history of the genus Nothofagus Bl.

(Fagaceae) in the Southern Hemisphere. J Fac Sci Hokkaido University IV 21: 505-582.

Taylor F, RS Hill 1996. A phylogenetic analysis of the Eucryphiaceae. Aust Syst Bot 9: 735748. 
Table 1. Fossil Nothofagus species used in this analysis, with known age ranges, region and location of original descriptions

\begin{tabular}{lllll}
\hline Species & Age & Region & Subgenus & Descriptions \\
\hline N. pachyphylla G. J. Jord. & Early & Tasmania & Lophozonia & Jordan (in press) \\
& Pleistocene & & & \\
N. tasmanica R.S.Hill & Oligocene & Tasmania & Lophozonia & Hill (1983; 1991); Scriven and Hill (1996) \\
N. maidenii (Deane)M.S.Pole & Late Oligocene & Tasmania/ & Lophozonia & Deane (1902); Pole et al. (1993); Hill (1983) \\
& /Early Miocene & SE & & \\
& & Australia & & \\
N. lobata R.S.Hill & Early Oligocene & Tasmania & Nothofagus & Hill (1991); Scriven and Hill (1996) \\
N. microphylla R.S.Hill & Late Oligocene & Tasmania & Nothofagus & Hill (1991); Scriven and Hill (1996) \\
& /Early Miocene & & & \\
N. mucronata R.S.Hill & Early Oligocene & Tasmania & Brassospor & Hill (1991) \\
& & & $a$ & \\
N. serrata R.S.Hill & Early Oligocene & Tasmania & Brassospor & Hill (1991) \\
& & & $a$ & \\
\hline
\end{tabular}


Table 2. Morphological characters used in the cladistic analyses

\begin{tabular}{|c|c|}
\hline Character & States \\
\hline \multirow[t]{4}{*}{ 1. Leaf vernation } & $0=$ plicate \\
\hline & $1=$ planar \\
\hline & $2=$ revolute \\
\hline & $3=$ conduplicate \\
\hline \multirow[t]{6}{*}{ 2.Cupules valves and fruit } & $1=$ valves 4 , fruit 2 trimerous, 1 dimerous \\
\hline & $2=$ valves 2, fruit 3 dimerous \\
\hline & $3=$ valves 2 , fruit 1 dimerous \\
\hline & $4=$ valves 2, fruit 1 trimerous \\
\hline & $5=$ valves $2-4$, fruit 1 trimerous, $0-1$ \\
\hline & $6=$ valves 4, fruit $4-7$ \\
\hline \multirow[t]{2}{*}{ 3. Cupule appendage type } & $0=$ glandular \\
\hline & 1 = lamellate \\
\hline \multirow[t]{2}{*}{ 4. Peduncle length } & $0=$ sessile or short \\
\hline & $1=$ long \\
\hline \multirow[t]{3}{*}{ 5. Cupule valves } & $0=$ woody \\
\hline & $1=$ thin \\
\hline & $2=$ thin and much shorter than the fruit. \\
\hline \multirow[t]{2}{*}{ 6. Staminate flowers } & $0=$ perianth present \\
\hline & $1=$ perianth absent, pseudanthium present \\
\hline \multirow[t]{2}{*}{ 7. Pollen shape in polar view } & $0=$ peritreme \\
\hline & 1 = goniotreme \\
\hline \multirow[t]{2}{*}{ 8. Pollen polar to equatorial lengths ( $1 / \mathrm{E})$} & $0=1 / \mathrm{E}>0.35$ \\
\hline & $1=1 / E<0.3$ \\
\hline \multirow[t]{4}{*}{ 9. Pollen aperture thickening } & $0=$ annulate \\
\hline & $1=$ heavy thickening \\
\hline & $2=$ rimmed \\
\hline & $3=$ unthickened \\
\hline \multirow[t]{2}{*}{ 10. Pollen equatorial diameter } & $0=<65 \mu \mathrm{m}$ \\
\hline & $1=>65 \mu \mathrm{m}$ \\
\hline \multirow[t]{2}{*}{ 11. Wood anatomy } & $0=$ tracheids present \\
\hline & $1=$ tracheids absent \\
\hline \multirow[t]{2}{*}{ 12. Stipule attachment } & $0=$ not peltate \\
\hline & $1=$ peltate \\
\hline \multirow[t]{2}{*}{ 13. Phyllotaxy } & $0=$ distichous \\
\hline & $1=$ spiral \\
\hline \multirow[t]{2}{*}{ 14. Glandular trichomes on cuticle } & $0=$ present \\
\hline & $1=$ absent \\
\hline \multirow[t]{2}{*}{ 15. Solitary unicellular trichome type A (SUTTA) } & $0=$ present \\
\hline & $1=$ absent \\
\hline \multirow{2}{*}{ 16. Solitary unicellular trichome type C (SUTTC) } & $0=$ present \\
\hline & $1=a b s e n t$ \\
\hline \multirow[t]{4}{*}{ 17. Conical trichomes } & $0=$ present \\
\hline & $1=$ absent \\
\hline & $2=$ broad based form \\
\hline & $3=$ SUTTB or SUTTD \\
\hline \multirow[t]{2}{*}{ 18. $\mathrm{T}$ - pieces at stomatal poles } & $0=\mathrm{absent}$ \\
\hline & $1=$ present \\
\hline \multirow[t]{2}{*}{ 19. Stomatal orientation } & $0=$ random \\
\hline & $1=$ mostly parallel with the midrib \\
\hline \multirow[t]{2}{*}{ 20. Giant stomata on veins } & $0=$ present \\
\hline & $1=\mathrm{absent}$ \\
\hline
\end{tabular}


21. Stomatal size excluding giant stomata

22. Upper epidermal cells over veins

23. Complete fimbrial vein

24. Serrations

\author{
$0=$ more or less even \\ $1=$ variable \\ $0=$ more elongate than areolar cells \\ $1=$ not distinguishable from areolar cells \\ $2=$ thinner than areolar cells \\ $0=$ absent \\ $1=$ type 1 \\ $2=$ type 2 \\ $0=$ often associated with more than two \\ teeth \\ $1=$ associated with one or two teeth \\ $2=$ entire margined leaf
}


Table 3. Matrix of morphological data for cladistic analysis. Note that the fossils are coded for only characters 14 - 24

\begin{tabular}{|c|c|c|c|c|c|c|c|c|c|c|c|c|c|c|c|c|c|c|c|c|c|c|c|c|c|}
\hline Taxon & 1 & 2 & 3 & 4 & 5 & 6 & 7 & 8 & 9 & 10 & 11 & 12 & 13 & & 4 & 15 & 16 & 17 & 18 & 19 & 20 & 21 & 22 & 23 & $\overline{24}$ \\
\hline Outgroup & 0 & $?$ & $?$ & $?$ & $?$ & $?$ & $?$ & $?$ & $?$ & $?$ & 0 & 0 & ( & & 0 & 1 & 0 & 0 & 0 & 0 & 0 & 1 & 0 & 0 & $\overline{0}$ \\
\hline N. aequilateralis (Baum.-Baudenh.) Steenis & 3 & 2 & 1 & 0 & 0 & 0 & 1 & 1 & 2 & 0 & 1 & 1 & 1 & & 0 & 1 & 1 & 0 & 0 & 0 & 0 & 0 & 2 & 0 & 2 \\
\hline N. alessandri Espin. & 0 & 6 & 1 & 0 & 1 & 0 & 0 & 1 & 1 & 0 & 0 & 0 & ( & & 0 & 0 & 1 & 1 & 0 & 0 & 1 & 1 & 0 & 0 & 1 \\
\hline N. alpina Phil. & 0 & 1 & 0 & 0 & 1 & 1 & 1 & 0 & 3 & 1 & 0 & 0 & ( & & 0 & 1 & 0 & 0 & 0 & 0 & 1 & 1 & 0 & 0 & 0 \\
\hline N. $\operatorname{antarctica}(\mathrm{G}$. Forst.) Oerst. & 0 & 1 & 1 & 0 & 1 & 0 & 0 & 1 & 0 & 0 & 0 & 1 & ( & & 0 & 1 & 1 & 0 & 1 & 1 & 1 & 1 & 0 & 0 & 0 \\
\hline N. balansae (Baill.) Steenis & 3 & 2 & 1 & 0 & 0 & 0 & 1 & 1 & 2 & 0 & 1 & 1 & 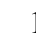 & & 0 & 1 & 1 & 1 & 0 & 0 & 0 & 0 & 2 & 1 & 1 \\
\hline N. betuloides (Mirb.) Oerst. & 1 & 1 & 0,1 & 0 & 1 & 0 & 0 & 1 & 0 & 0 & 0 & 1 & ( & & 0 & 1 & 1 & 0 & 1 & 1 & 1 & 1 & 0 & 0 & 0 \\
\hline$N$. brassii Steenis & 3 & 2 & 1 & 1 & 1 & 0 & 1 & 1 & 2 & 0 & 1 & 1 & ( & & 0 & 1 & 1 & 1 & 0 & 0 & 0 & 0 & 2 & 0 & 2 \\
\hline N. cunninghamii Oerst. & 1 & 1 & 0 & 0 & 1 & 1 & 1 & 0 & 3 & 1 & 0 & 0 & ( & & 0 & 1 & 0 & 2 & 0 & 0 & 0 & 1 & 1 & 0 & 1 \\
\hline N. dombeyi $\mathrm{Bl}$. & 1 & 1 & 1 & 0 & 1 & 0 & 0 & 1 & 0 & 0 & 0 & 1 & ( & & 0 & 1 & 1 & 0 & 1 & 1 & 1 & 0 & 0 & 0 & 0 \\
\hline N. fusca Oerst. & 2 & 1 & 1 & 0 & 1 & 0 & 0 & 1 & 1 & 0 & 0 & 0 & ( & & 0 & 0 & 1 & 0 & 0 & 0 & 1 & 1 & 0 & 1 & 1 \\
\hline N. glauca (R. Phil.)Krasser & 0 & 1 & 0 & 0 & 1 & 1 & 1 & 0 & 3 & 1 & 0 & 0 & ( & & 0 & 1 & 0 & 0 & 0 & 0 & 1 & 1 & 0 & 0 & 0 \\
\hline N. grandis Steenis & 3 & 3 & 1 & 0 & 1 & 0 & 1 & 1 & 2 & 0 & 1 & 1 & ( & & 0 & 1 & 1 & 1 & 0 & 0 & 0 & 0 & 2 & 0 & 2 \\
\hline N. gunnii (Hook. f.) Oerst. & 0 & 1 & 1 & 0 & 1 & 0 & 0 & 1 & 1 & 0 & 0 & 0 & ( & & 1 & 0 & 1 & 0 & 0 & 0 & 1 & 1 & 0 & 0 & 1 \\
\hline N. menziesii Oerst. & 1 & 1 & 0 & 0 & 1 & 1 & 1 & 0 & 3 & 1 & 0 & 0 & ( & & 0 & 1 & 0 & 2 & 0 & 0 & 1 & 1 & 1 & 2 & 0 \\
\hline N. moorei Maiden & 1 & 1 & 0 & 0 & 1 & 1 & 1 & 0 & 3 & 1 & 0 & 0 & ( & & 0 & 1 & 0 & 2 & 0 & 0 & 1 & 1 & 1 & 2 & 0 \\
\hline N. nitida Reiche & 1 & 1 & 1 & 0 & 1 & 0 & 0 & 1 & 0 & 0 & 0 & 1 & ( & & 0 & 1 & 1 & 0 & 1 & 1 & 1 & 0 & 1 & 0 & 0 \\
\hline N. obliqua $\mathrm{Bl}$. & 0 & 1 & 0 & 0 & 1 & 1 & 1 & 0 & 3 & 1 & 0 & 0 & ( & & 0 & 1 & 0 & 0 & 0 & 0 & 1 & 1 & 0 & 0 & 0 \\
\hline N. perryi Steenis & 3 & 2 & 1 & 1 & 1 & 0 & 1 & 1 & 2 & 0 & 1 & 1 & ( & & 0 & 1 & 1 & 1 & 0 & 0 & 0 & 0 & 1 & 0 & 1 \\
\hline N. pumilio (Poepp. \& Endl.) Krasser & 0 & 4 & 0,1 & 0 & 1 & 0 & 0 & 1 & 0 & 0 & 0 & 1 & ( & & 0 & 1 & 1 & 3 & 1 & 1 & 1 & 1 & 0 & 0 & 0 \\
\hline N. resinosa Steenis & 3 & 3 & 1 & 0 & 2 & 0 & 1 & 1 & 2 & 0 & 1 & 1 & ( & & 0 & 1 & 1 & 0 & 0 & 0 & 0 & 0 & 2 & 1 & 1 \\
\hline N. solandri Oerst. & 2 & 5 & 1 & 0 & 1 & 0 & 0 & 1 & 1 & 0 & 0 & 0 & ( & & 1 & 0 & 1 & 1 & 0 & 0 & 1 & 1 & 0 & 1 & 2 \\
\hline N. truncata Cockayne & 2 & 1 & 1 & 0 & 1 & 0 & 0 & 1 & 1 & 0 & 0 & 0 & ( & & 0 & 0 & 1 & 1 & 0 & 0 & 1 & 1 & 0 & 1 & 1 \\
\hline
\end{tabular}


Fossil species

$N$. mucronatal N. serrata

N. lobata

N. microphylla

N. pachyphylla

N. tasmanica

N. maidenii

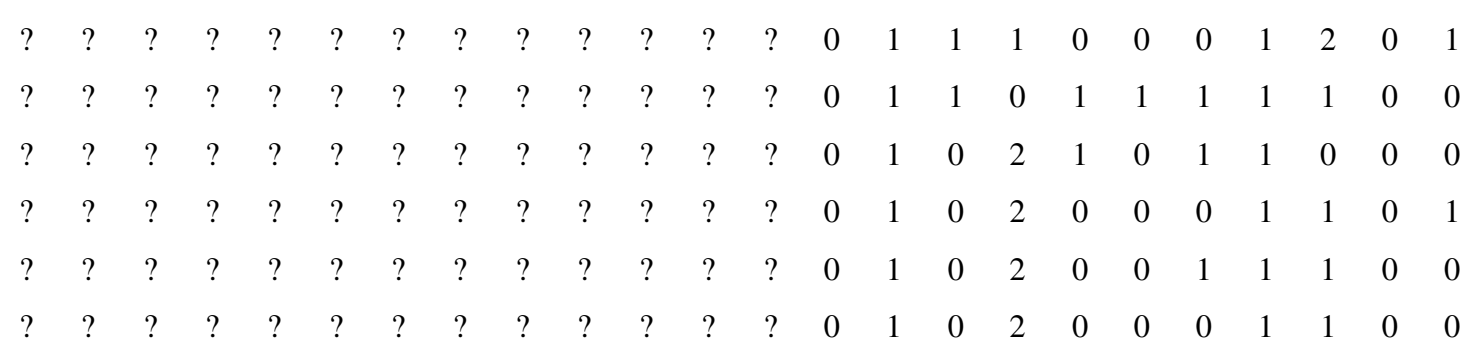


Table 4. Data sets for cladistic analyses of fossil and extant Nothofagus species. Note that analyses 3 to 24 includes one analysis for each extant species, and analyses 26-31 include one analysis for each fossil terminal

\begin{tabular}{lll}
\hline Analysis number & Taxa & Characters \\
\hline 1 & All extant species & All \\
2 & All extant species & Morphological characters 14 - 24 \\
$2-23$ & All extant species & Morphological characters 14 - 24 for one extant species \\
& & plus all characters for the other 21 \\
24 & All extant and fossil species & All \\
25 & All extant and fossil species & Morphological characters 14 - 24 \\
$26-31$ & All extant species plus one fossil taxon & All \\
32 & All extant species & Morphological characters $14-24$ \\
\hline
\end{tabular}


Table 5. Consistency indices of leaf morphological and anatomical characters in trees based on a combined analyses of morphological and molecular data. Indices are given for the two trees without fossils (Fig. 2) and for the 90 trees with fossils (Fig.4)

\begin{tabular}{lrrr}
\hline Character & minimum steps & without fossils & with fossils \\
\hline Cuticular traits & 1 & 0.5 & 0.5 \\
14. Glandular trichomes & 1 & 1 & 1 \\
15. SUTTA & 1 & 1 & 1 \\
16. SUTTC & 3 & 0.43 & 0.43 \\
17. Conical trichomes & 1 & 1 & 0.5 \\
18. T- pieces & 1 & 1 & 1 \\
19. Stomatal orientation & 1 & 0.33 & 0.33 \\
20. Giant stomata & 1 & 0.33 & 0.33 \\
21. Stomatal size & 2 & 0.5 & 0.5 \\
22. Adaxial epidermis & & & 0.4 \\
Architectural traits & 2 & 0.4 & 0.29 \\
23. Complete fimbrial vein & 2 & 0.33 & \\
24. Multiple teeth & & & \\
\hline
\end{tabular}



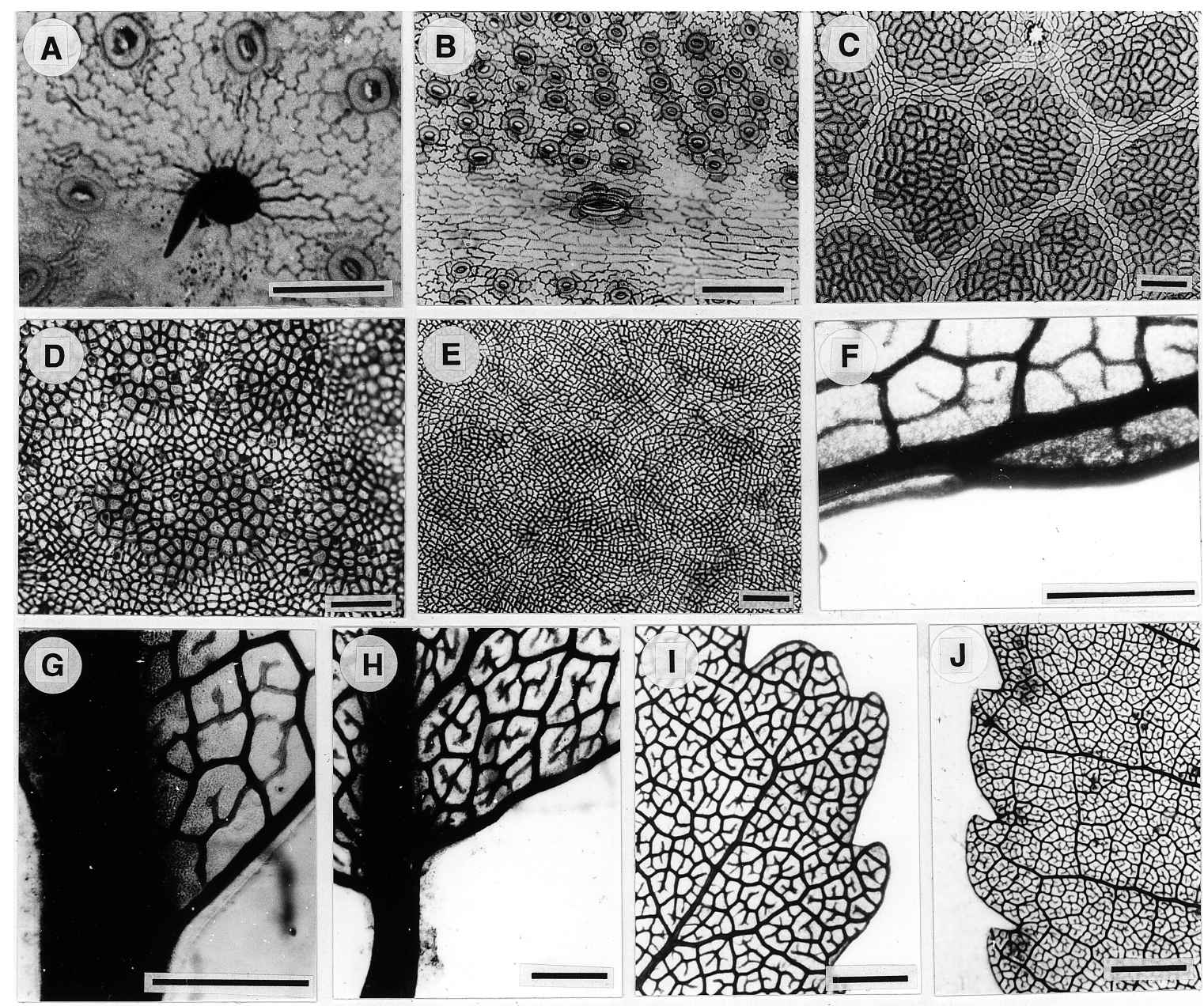

Fig. 1 Leaf architectural and cuticular features. Fig. 1A, Conical trichome of N. cunninghamii showing the very broad base with a short trichome. Fig. 1B, Cuticle of $N$. cunninghamii showing a giant stoma. Fig. 1C, Cuticle of adaxial surface of $N$. dombeyi showing reticulations. Fig. 1D, Cuticle of adaxial surface of $N$. resinosa showing reticulations with bulging cells in the areoles. Fig. 1E, Cuticle of adaxial surface of $N$. menziesii showing uniform cell size. Fig. 1F, Leaf margin of N. moorei showing the fimbrial vein arising from the basal secondary vein. Fig. 1G, Leaf margin of $N$. fusca showing the fimbrial vein arising in the petiole. Fig. 1H, Margin of a cleared N. solandri leaf showing the well developed fimbrial vein. Fig. 1I, Margin of a cleared N. menziesii leaf showing multiple teeth. Fig. 1J, Margin of a cleared $N$. fusca leaf showing single teeth. Scale bars $50 \mu \mathrm{m}$ in Fig. 1A, $100 \mu \mathrm{m}$ in Figs 1B1E, $1 \mathrm{~mm}$ in Figs $1 \mathrm{G}-1 \mathrm{~J}$. 


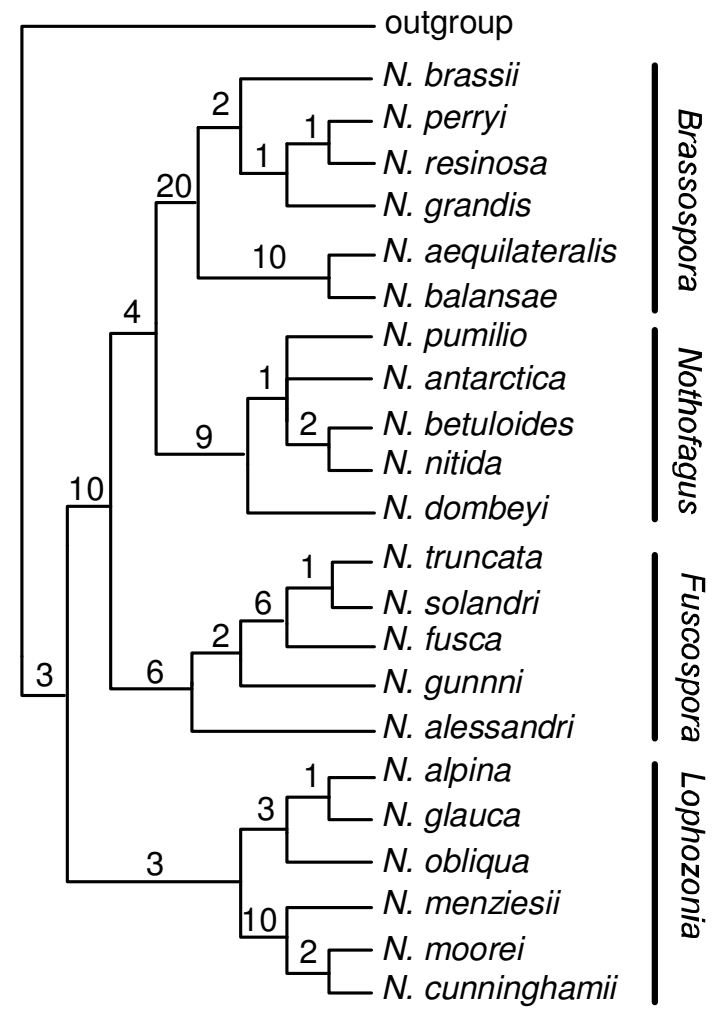

Fig. 2 The strict consensus of the two most parsimonious tree derived from the combined analysis of extant species (analysis 1). The Bremer support is shown above each branch. All morphological characters and 121 molecular characters were informative. The tree length was 365 steps and the consistency index excluding uninformative characters is 0.66 . 


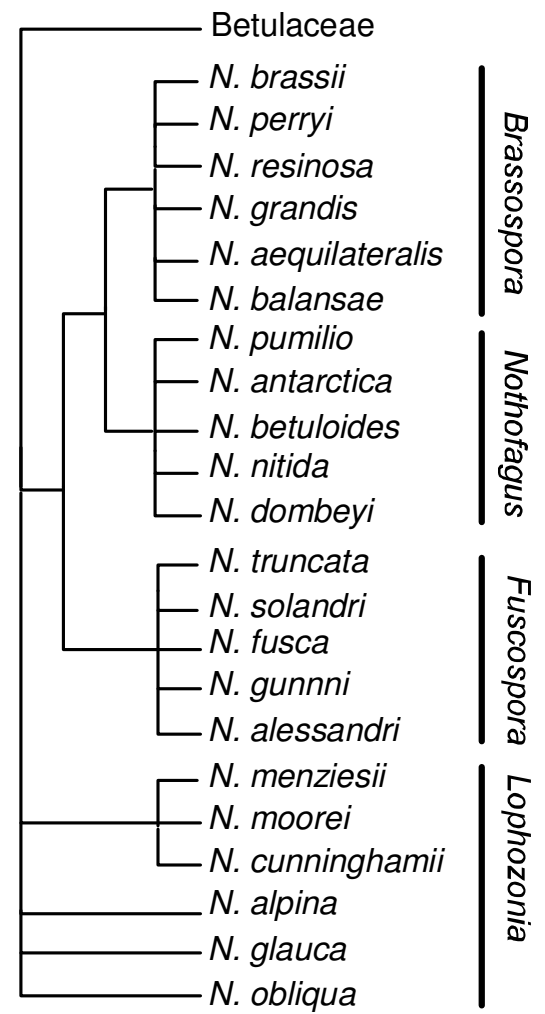

Fig. 3 The strict consensus of most parsimonious trees from analyses 2-23. This is the strict consensus of 22 strict consensus trees where data for one extant species at a time was restricted to those characters that can be measured on leaf fossils. The number of trees per analysis varied from 1 to 16 . This is a test of the power of the methods used here to place fossils phylogenetically. 


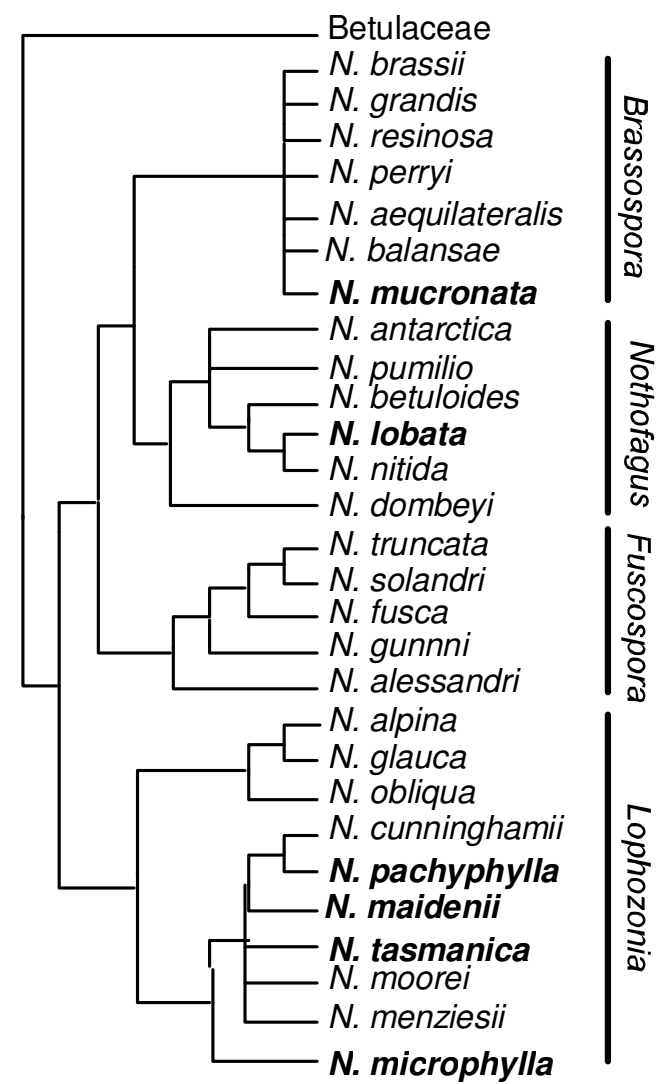

Fig. 4 A strict consensus of the 90 most parsimonious trees for both fossil and extant species using combined DNA and morphological data (analysis 24). All morphological characters and 121 molecular characters were informative. Excluding uninformative characters, the tree was 367 steps long with a consistency index of 0.66. Fossils names are in bold type. 
A

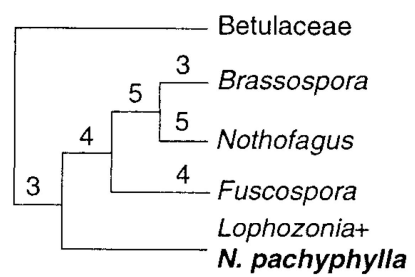

C

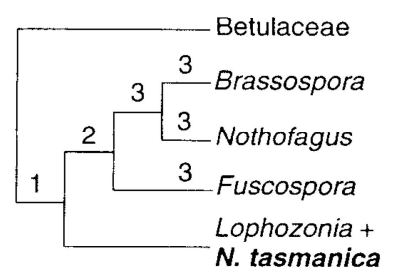

$\mathrm{E}$

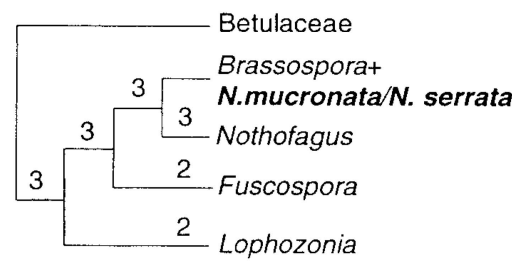

B

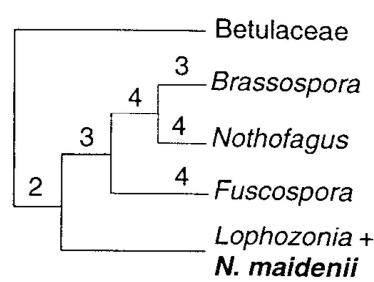

D

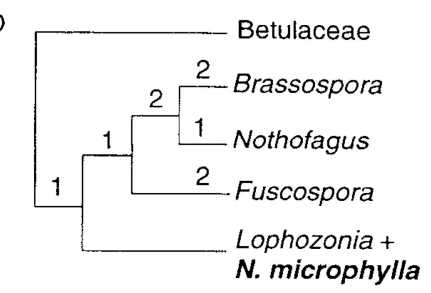

$\mathrm{F}$

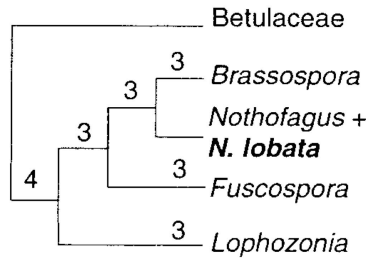

Fig. 5 Parsimony of alternative placements of fossils on the most parsimonious tree. The trees are collapsed to the subgeneric level. The numbers above the branches are the minimum additional number of extra steps for the fossil taxon to be placed on that branch. The positions of species within subgenera were unconstrained. Fig. 5A, N. pachyphylla (analysis 26). Fig. 5B, N. maidenii (analysis 27). Fig. 5C, N. tasmanica (analysis 28). Fig. 5D, N. microphylla (analysis 29). Fig. 5E, N. mucronata and N. serrata (analysis 30). Fig. 5F, N. lobata (analysis 31). 


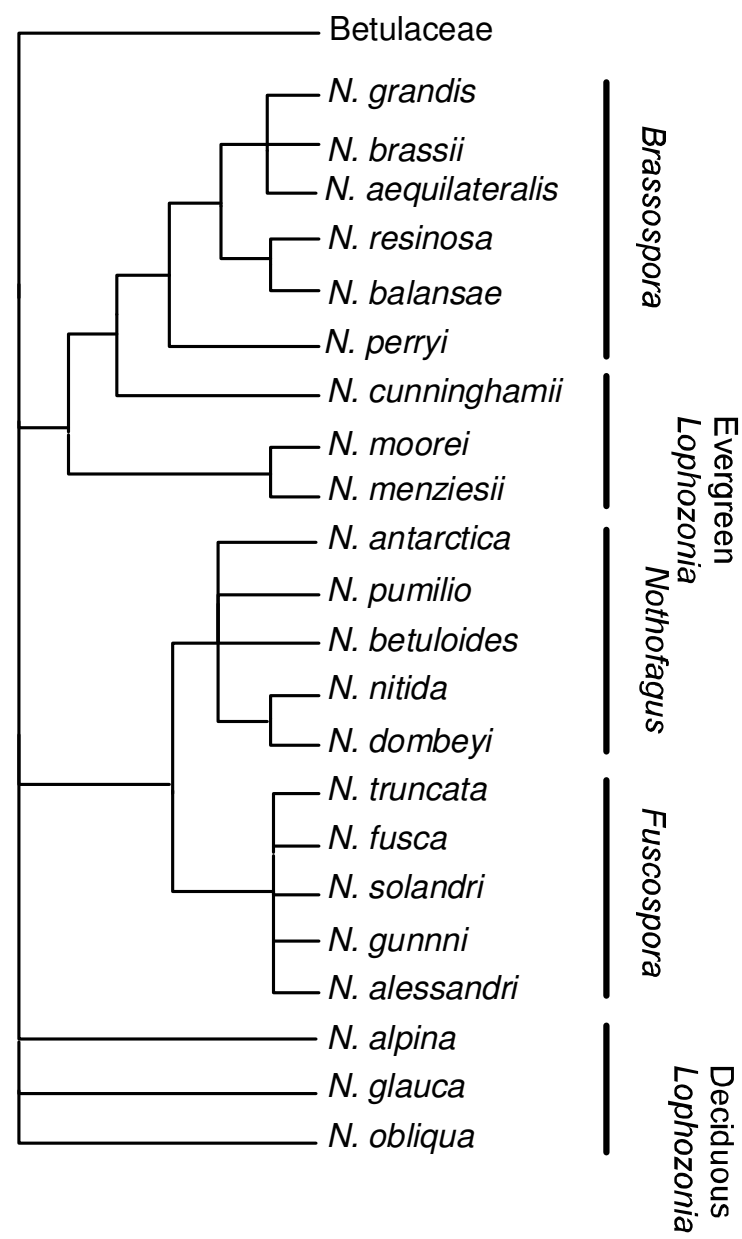

Fig. 6 The strict consensus of 12 most parsimonious trees for extant species using only morphological characters which can be scored on leaf fossils (characters 14-24). The tree length was 28 steps and the consistency index was 0.57 . Note the general congruence with the combined analysis of morphological and molecular data, apart from the evergreen members of subgenus Lophozonia (Fig. 2), and the poorer resolution. 